\title{
Loss-of-Function Mutations in the Dpp and Opp Permeases Render Erwinia amylovora Resistant to Kasugamycin and Blasticidin S
}

\author{
Yixin Ge, ${ }^{1,2}$ Jae Hoon Lee, ${ }^{2}$ Baishi Hu, ${ }^{1, \dagger}$ and Youfu Zhao ${ }^{2,+}$ \\ ${ }^{1}$ College of Plant Protection and Key Laboratory of Integrated Management of Crop Diseases and Pests, Nanjing Agricultural \\ University, Nanjing, 210095, P. R. China; and ${ }^{2}$ Department of Crop Sciences, University of Illinois at Urbana-Champaign, \\ Urbana, IL 61801, U.S.A.
}

Accepted 20 February 2018.

Extensive use of the antibiotic streptomycin to control fire blight disease of apples and pears, caused by the enterobacterial plant pathogen Erwinia amylovora, leads to the development of streptomycin-resistant strains in the United States and elsewhere. Kasugamycin (Ksg) has been permitted to be used as an alternative or replacement to control this serious bacterial disease. In this study, we investigated the role of two major peptide ATP-binding cassette transporter systems in E. amylovora, the dipeptide permease (Dpp) and oligopeptide permease (Opp), in conferring sensitivity to Ksg and blasticidin $\mathrm{S}(\mathrm{BcS})$. Minimum inhibitory concentration and spot dilution assays showed that the $d p p$ deletion mutants exhibited slightly enhanced resistance to Ksg in rich medium, whereas the opp mutant exhibited slightly enhanced resistance to Ksg in minimal medium and BcS in rich medium. Deletion of both $d p p$ and opp conferred a higher level of resistance to $\mathrm{Ksg}$ in both rich and minimal media, whereas deletion of opp alone was sufficient to confer high level of resistance to $\mathrm{BcS}$ in minimal medium. In addition, bioinformatic analysis combined with reverse transcription-quantitative polymerase chain reaction showed that the Res phosphorelay system negatively regulates opp expression and the $\operatorname{rcs} B$ mutant was more sensitive to both $\mathrm{Ksg}$ and $\mathrm{BcS}$ in minimal medium as compared with the wild type. An electrophoresis motility shift assay further confirmed the direct binding of the $R \operatorname{cs} A / \operatorname{ResB}$ proteins to the promoter region of the opp operon. However, neither the Dpp nor the Opp permeases contributed to disease progress on immature pears, hypersensitive response on tobacco leaves, or exopolysaccharide amylovoran production. These results suggested that Ksg and BcS employ the Dpp and Opp permeases to enter E. amylovora cells and the Dpp and Opp permeases act synergistically for illicit transport of antibiotics.

Yixin Ge and Jae Hoon Lee contributed equally to this work.

${ }^{\dagger}$ Corresponding authors: Baishi Hu; E-mail: hbs@njau.edu.cn and Youfu Zhao; E-mail: zhao888@illinois.edu

Funding: This project was supported by USDA-NIFA-AFRI Competitive Grants Program number 2016-67013-24812 and USDA-Hatch Project ILLU-802-913 (YFZ). Y. Ge thanks the China Scholarship Council for their financial support.

*The $e$-Xtra logo stands for "electronic extra" and indicates that one supplementary table is published online.

(c) 2018 The American Phytopathological Society
Fire blight disease, caused by gram-negative bacterium Erwinia amylovora, is a worldwide destructive disease of pome fruit trees, resulting in severe economic losses to the apple and pear industry. Annual average losses and cost of fire bight control exceed \$100 million in the United States alone (Norelli et al. 2003). The disease is indigenous to North America but has spread to over 50 countries and recently reached Russia and central and east Asia, the native origin of apple germplasm resources, including Iran, Kyrgyzstan, Kazakhstan, and South Korea (Myung et al. 2016; van der Zwet et al. 2012; Zhao 2014). E. amylovora infects all the aerial parts of a susceptible plant, including blossoms, fruits, vegetative shoots, woody tissues, and rootstock crowns and often produces creamy ooze at diseased part (Zhao 2014). Since the 1970s, multiple spray applications of streptomycin have been the most effective way of controlling blossom blight (McManus et al. 2002). However, the occurrence of streptomycin resistance in the United States, Canada, and elsewhere has rendered this antibiotic less effective (Coyier and Covey 1975; McManus et al. 2002). Other chemical compounds, such as oxytetracycline, are recommended for controlling fire blight disease but are less effective than streptomycin. Furthermore, naturally occurring oxytetracycline-resistant isolates were recently reported in California (Adaskaveg et al. 2008).

A promising alternative for fire blight management is kasugamycin (Ksg), which was discovered from Streptomyces kasugaensis and Streptomyces kasugaspinus in the 1960s to control rice blast disease (Schluenzen et al. 2006; Umezawa et al. 1965). Like streptomycin, Ksg is also an aminoglycoside antibiotic that inhibits translation but with a different mode of action (Copping and Duke 2007). The known target for Ksg in Escherichia coli is the $k s g A$ gene, which encodes an adenine demethylase (Vila-Sanjurjo et al. 1999). Ksg is known to protect nucleotides (such as A794 and G926) of the 16S ribosomal RNA from modification, and resistance to Ksg arises from lack of modification of these bases or mutations in the $k s g A$ gene (Mankin 2006). Ksg has been used as a bactericide for fire blight control in the early 1990s and was only recently proven to have similar efficacy as streptomycin in field applications (Adaskaveg et al. 2008; 2011; McGhee and Sundin 2011). On the other hand, blasticidin $\mathrm{S}(\mathrm{BcS})$ is a nucleoside antibiotic produced by Streptomyces griseochromogenes and is also widely used as a fungicide for rice blast disease in Japan, Korea, and South America (Shiver et al. 2016; Takeuchi et al. 1958). BcS specifically inhibits protein synthesis in both prokaryotes and eukaryotes (Yamaguchi et al. 1965). Recent studies in Escherichia coli showed that Ksg and BcS hijack 
dipeptide permease (Dpp) and oligopeptide permease (Opp), two sets of peptide ATP-binding cassette (ABC) importer systems, to enter the cell, and mutations of these two systems resulted in increased resistance to $\mathrm{Ksg}$ and $\mathrm{BcS}$ in minimal medium (Shiver et al. 2016).

Both the Dpp and Opp systems are periplasmic binding protein-dependent transport systems. The operon structure $(d p p A-F$ and $o p p A-F)$ (Fig. 1) and gene sequences of the two systems are highly conserved in E. amylovora and Escherichia coli (Table 1) as well as among many bacterial species (Borezee et al. 2000; Hiles and Higgins 1986; Hiles et al. 1987; Manson et al. 1986). The Dpp system is associated with the import of dipeptides and tripeptides as well as heme and short-chain peptides, depending on the side chains (Létoffé et al. 2006; Pletzer et al. 2014; 2015; Smith et al. 1999). Transportation of glycylsarcosine in E. coli also depends on the Dpp system (Payne et al. 2001). In Helicobacter pylori, the Dpp is part of the nickel acquisition and distribution network (Davis and Mobley 2005). The Dpp system also participates in the uptake of essential amino acids and positively regulates the expression of cysteine protease in Streptococcus pyogenes (Podbielski and Leonard 1998).

On the other hand, the Opp system plays important roles not only in nutrient uptake but also in recycling cell-wall peptides and sensing environments (Alloing et al. 2006; Goodell and Higgins 1987; Koning et al. 2001; Yoon et al. 2016). As a virulence factor, the Opp system mediates the acquisition of limiting nutrients such as nickel and cobalt and facilitates persistence and virulence of Moraxella catarrhalis and Staphylococcus aureus (Hiron et al. 2010; Jones et al. 2014; Remy et al. 2013). In Pseudomonas aeruginosa, mutation of the opp operon conferred high level of resistance against pacidamycin, an antibiotic produced by Streptomyces coeruleorubidus (Mistry et al. 2013). Furthermore, mutation of opp in Bacillus subtilis affects toxic tripeptide bialaphos resistance and sporulation and inhibits the biosynthesis of bacilysin (Solomon et al. 2003; Yazgan et al. 2001). However, the role of the Dpp and Opp systems in nutrient uptake, virulence, and conferring antibiotic sensitivity remains unknown in E. amylovora. In this study, we investigated the role of the Dpp and Opp permeases of E. amylovora in $\mathrm{Ksg}$ and $\mathrm{BcS}$ uptake and virulence. Our results showed that, though both the Dpp and Opp systems were not required for virulence, loss-offunction mutations in both complexes resulted in higher levels of resistance to $\mathrm{Ksg}$ and $\mathrm{BcS}$. We further demonstrated that the Rcs phosphorelay system negatively regulated $o p p$ expression.

\section{RESULTS}

\section{Two $\operatorname{dpp} A$ and $о p p A$ genes are present in the Erwinia amylovora genome.}

Based on published genome sequences of E. amylovora (Smits et al. 2010, 2011), the oppA-F (Eam_RS09140-RS09120) and $d p p A-F$ (Eam_RS16685-RS16665) operons are very conserved with those in Escherichia coli (Fig. 1; Table 1). The deduced amino acids for the oppA-F and $d p p A-F$ genes in E. amylovora and Escherichia coli shared 74 to $91 \%$ identities and 90 to $99 \%$ similarities (Table 1). Besides, E. amylovora genome contains $d p p A$ and oppA homologs, hereby named dppA2 (Eam_RS08570) and oppA2 (Eam_RS09145), respectively (Fig. 1). The deduced amino acid of the orphan

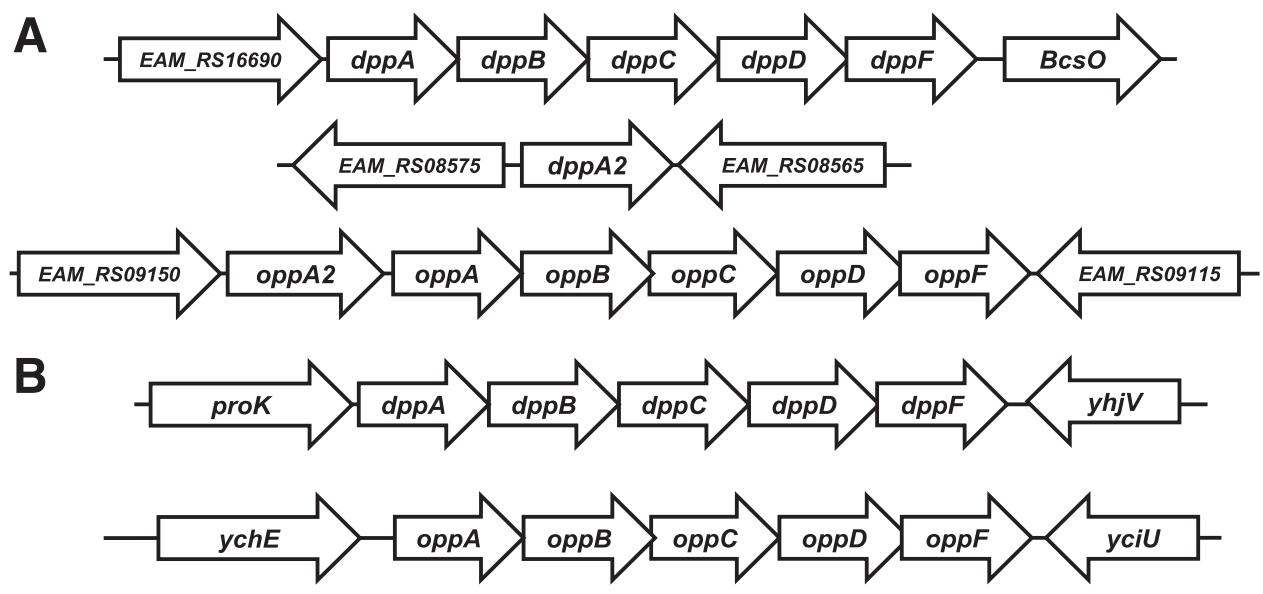

Fig. 1. Schematic maps of the $d p p$ and opp genes or operons in $\mathbf{A}$, Erwinia amylovora genome and $\mathbf{B}$, Escherichia coli. The genome sequence accession number for E. amylovora Ea273 is NC_013971 and for Escherichia coli K-12 strain MG1655 is NC_00913.

Table 1. Comparison of deduced amino acid sequences for the Dpp and Opp systems in Erwinia amylovora and Escherichia coli ${ }^{\text {a }}$

\begin{tabular}{|c|c|c|c|c|c|c|c|}
\hline Protein & Length & Identity & Similarity & Protein & Length & Identity & Similarity \\
\hline Ea DppA & 536 & - & - & Ea OppA & 543 & - & - \\
\hline Ea DppA2 & 532 & 62.9 & 86.9 & Ea OppA2 & 541 & 56.2 & 85.5 \\
\hline Ec DppA & 535 & 80.6 & 94.2 & Ec OppA & 543 & 73.7 & 89.9 \\
\hline Ea DppB & 339 & - & - & Ea OppB & 306 & - & - \\
\hline Ec DppB & 339 & 88.5 & 96.5 & Ec OppB & 306 & 90.5 & 98.4 \\
\hline Ea DppC & 300 & - & - & Ea OppC & 302 & - & - \\
\hline Ec DppC & 300 & 85.7 & 95.0 & Ec OppC & 302 & 89.4 & 98.7 \\
\hline Ea DppD & 328 & - & - & Ea OppD & 338 & - & - \\
\hline Ec DppD & 327 & 86.9 & 96.3 & Ec OppD & 337 & 84.6 & 93.8 \\
\hline Ea DppF & 333 & - & - & $\mathrm{Ea} O p p F$ & 333 & - & - \\
\hline Ec DppF & 334 & 84.1 & 93.7 & Ec OppF & 334 & 87.4 & 97.3 \\
\hline
\end{tabular}

${ }^{\mathrm{a}} \mathrm{Ea}=$ Erwinia amylovora Ea273, genome sequence accession number NC_013971 and Ec = Escherichia coli $K$-12, accession number NC_00913. 
$d p p A 2$ gene shared $63 \%$ identity and $87 \%$ similarity with E. amylovora DppA (Table 1), whereas oppA2 is the first gene in the oppA-F operon and its deduced amino acid shared about $56 \%$ identity and $86 \%$ similarity with E. amylovora OppA (Table 1).

\section{The $d p p A-F$ and $o p p A-F$ operons are dispensable for virulence of $E$. amylovora.}

To understand the role of these two operons in E. amylovora, we generated nine mutants, i.e., $d p p A, d p p A 2, o p p A, o p p A 2$, dppA-F, орpA2-F, dppA/oppA, $d p p A 2 / o p p A 2$, and $d p p A-$ $F / o p p A 2-F$ (Table 2). First, we determined the virulence of the mutants by inoculating them on immature pear fruits (Zhao et al. 2009b). All mutants exhibited similar disease progress as the wild-type (WT) strain, i.e., the black necrotic lesion appeared with visible bacterial ooze formation at 4 days postinoculation (dpi) and the necrotic area expended to the whole fruits at 8 dpi (Fig. 2A). Similarly, all mutants induced a hypersensitive response (HR) as did the WT (Fig. 2B). In addition, motility and exopolysaccharide (EPS) amylovoran production mostly were not significantly changed in these mutants as compared with the WT, except for at $48 \mathrm{~h}$ motility was significantly reduced for the mutants (Fig. 2C and D). These results indicated that the Opp and Dpp systems are dispensable for E. amylovora virulence.

\section{The Dpp and Opp systems of $E$. amylovora confer} sensitivity to Ksg and BcS in Luria Bertani (LB) medium.

It has been reported, in Escherichia coli, that both Ksg and $\mathrm{BcS}$ hijack the Dpp and Opp systems to enter the cell and mutations in the $d p p$ and opp genes lead to higher levels of resistance to both antibiotics in minimal medium (Shiver et al. 2016). To examine whether the Dpp and Opp systems in E. amylovora function similarly, we first assessed the minimal inhibitory concentration (MIC) of $\mathrm{Ksg}$ and $\mathrm{BcS}$ in $\mathrm{LB}$ for the WT and the nine mutant strains as well as the $k s g A$ mutant, which encodes a target for Ksg in Escherichia coli and E. amylovora (McGhee and Sundin 2011; Vila-Sanjurjo et al. 1999). As shown in Table 3, the MIC of Ksg and BcS for the WT was 200 and $60 \mu \mathrm{g} / \mathrm{ml}$, respectively. The MIC of Ksg increased to $300 \mu \mathrm{g} / \mathrm{ml}$ in the $d p p A$ and $d p p A-F$ mutants and reached $400 \mu \mathrm{g} / \mathrm{ml}$ in the $d p p A / o p p A$ and $d p p A-F / o p p A 2-F$ mutants, which was similar to that of the $k s g A$ mutant (MIC at $400 \mu \mathrm{g} / \mathrm{ml}$ ) (Table 3). However, the oppA, oppA2, oppA2-F, $d p p A 2$, and $d p p A 2 / o p p A 2$ mutants remained at the WT level of resistance to $\mathrm{Ksg}$ (MIC at $200 \mu \mathrm{g} / \mathrm{ml}$ ). These results indicate that both Dpp and Opp systems synergistically contribute to the sensitivity to Ksg in E. amylovora and, also, suggest that the Dpp system plays a major role in transport of Ksg as compared with the Opp system in LB.

On the other hand, the $d p p A, d p p A 2$, and $d p p A-F$ mutants exhibited the same MIC of $\mathrm{BcS}$ as the WT at $60 \mu \mathrm{g} / \mathrm{ml}$, while a slightly increased MIC at $65 \mu \mathrm{g} / \mathrm{ml}$ was observed for the оррA, оррA2, орpA2-F, $d p p A / о p p A, \operatorname{dppA2/oppA2,~and~} d p p A$ F/oppA2-F mutants (Table 3 ). These results indicate that the Opp but not the Dpp, system is responsible for $\mathrm{BcS}$ sensitivity of E. amylovora in LB. Moreover, deletion of the $d p p A 2$ gene had no effects on the sensitivity to both $\mathrm{Ksg}$ and $\mathrm{BcS}$ antibiotics, indicating that DppA2 is not required for the Dpp function. However, it is still unclear for the function of the OppA2. The oppA2 mutant exhibited the same level of MIC as the oppA and oppA2- $F$ mutants, suggesting that OppA2 might contribute to the Opp function or the oppA2 gene, as the first gene of the opp operon, is required for the expression of other Opp components. Furthermore, when tested for sensitivity to oxytetracycline and streptomycin, all mutants were as sensitive as the WT (data not shown). Based on the MIC results above, the operon deletion mutants ( $d p p$ as $d p p A-F$, opp as oppA2-F, and $d p p / o p p$ as $d p p A$ $F / o p p A 2-F$ ) were used for the remainder of our studies.

\section{The Opp system renders E. amylovora sensitive to both Ksg and BcS \\ in modified basal minimal medium (MBMA).}

To further illustrate the role of the Dpp and Opp systems in bacterial growth and antibiotic resistance, we performed spot dilution assays on LB and MBMA plates. On LB plate without antibiotics, growth of the $d p p$, opp single, and dpp/opp double operon deletion mutant strains was equivalent to the WT strain (Fig. 3A, left). Consistent with the MIC results, on LB plates amended with Ksg at $200 \mu \mathrm{g} / \mathrm{ml}$, growth of the opp mutant was similar to the WT, whereas the $d p p$ mutant was slightly more resistant (at least one dilution lower) and the dpp/opp mutant showed the highest level of resistance to Ksg (four dilutions lower) as compared with the WT (Fig. 3A, middle). When LB plates amended with $\mathrm{BcS}$ at $60 \mu \mathrm{g} / \mathrm{ml}$, the opp and $d p p / o p p$ deletion mutants showed slightly increased resistance (one dilution lower) as compared with the $\mathrm{WT}$ and the $d p p$ mutant (Fig. 3A, right).

On MBMA plates without $\mathrm{Ksg}$ and $\mathrm{BcS}$, growth of all three mutants was equivalent to the WT strain (Fig. 3B, left). When

Table 2. Bacterial strains and plasmids used in this study

\begin{tabular}{|c|c|c|}
\hline Strains and plasmids & Description $^{\text {a }}$ & Reference or Source \\
\hline \multicolumn{3}{|l|}{ Erwinia amylovora } \\
\hline Ea1189 & Wild type, isolated from apple & Wang et al. 2009 \\
\hline$\triangle d p p A$ & $d p p A:: \mathrm{Cm} ; \mathrm{Cm}^{\mathrm{R}}$ insertional mutant of $d p p A$ gene of Ea1189 & This study \\
\hline$\triangle d p p A 2$ & $d p p A 2:: \mathrm{Cm} ; \mathrm{Cm}^{\mathrm{R}}$ insertional mutant of $d p p A 2$ gene of Ea1189 & This study \\
\hline$\Delta d p p A-F$ & $d p p A-d p p F:: \mathrm{Cm} ; \mathrm{Cm}^{\mathrm{R}}$ insertional mutant of $d p p A-F$ operon of Ea1189 & This study \\
\hline$\triangle о р p A$ & oppA::Cm; $\mathrm{Cm}^{\mathrm{R}}$ insertional mutant of oppA gene of Ea1189 & This study \\
\hline$\triangle о р p A 2$ & oppA2::Cm; $\mathrm{Cm}^{\mathrm{R}}$ insertional mutant of oppA2 gene of Ea1189 & This study \\
\hline$\triangle о р p A 2-F$ & oppA2-oppF::Cm; $\mathrm{Cm}^{\mathrm{R}}$ insertional mutant of oppA2-F operon of Ea1189 & This study \\
\hline$\triangle d p p A / о p p A$ & oppA::Km, dppA::Cm; $\mathrm{Km}^{\mathrm{R}}$ insertional mutant of oppA in $\triangle d p p A$ & This study \\
\hline$\triangle d p p A 2 / о р p A 2$ & oppA2::Km, $d p p A 2:: \mathrm{Cm} ; \mathrm{Km}^{\mathrm{R}}$ insertional mutant of oppA2 in $\triangle d p p A 2$ & This study \\
\hline$\Delta d p p A-F$ /орpA2-F & oppA2-oppF::Km; $\mathrm{Km}^{\mathrm{R}}$ insertional mutant of oppA2-F in $\triangle d p p A-F$ & This study \\
\hline$\Delta k s g A$ & $k s g A:: \mathrm{Cm} ; \mathrm{Cm}^{\mathrm{R}}$ insertional mutant of $k s g A$ gene of Ea1189 & This study \\
\hline$\Delta h r p L$ & hrpL:: $\mathrm{Km} ; \mathrm{Km}^{\mathrm{R}}$ insertional mutant of hrpL gene of Ea1189 & Ancona et al. 2014 \\
\hline$\Delta r c s B$ & $r c s B:: \mathrm{Km} ; \mathrm{Km}^{\mathrm{R}}$ insertional mutant of $r c s B$ gene of Ea1189 & Wang et al. 2009 \\
\hline \multicolumn{3}{|c|}{ - } \\
\hline pKD46 & ApR, PBAD gam bet exo pSC101 oriTS & Datsenko and Wanner 2000 \\
\hline pKD32 & $\mathrm{Cm}^{\mathrm{R}}$, FRT cat $\mathrm{FRT}$ tL3 oriR6K $\gamma$ bla $\operatorname{rgn} B$ & Datsenko and Wanner 2000 \\
\hline pKD13 & $\mathrm{Km}^{\mathrm{R}}$, FRT kan FRT tL3 oriR6K $\gamma$ bla rgnB & Datsenko and Wanner 2000 \\
\hline
\end{tabular}

${ }^{\mathrm{a}} \mathrm{Cm}^{\mathrm{R}}, \mathrm{Km}^{\mathrm{R}}$, = chloramphenicol- and kanamycin-resistant. 
MBMA plates amended with $\mathrm{Ksg}$ at $50 \mu \mathrm{g} / \mathrm{ml}$ or $\mathrm{BcS}$ at $15 \mu \mathrm{g} / \mathrm{ml}$, growth of the $d p p$ mutant and the WT was also similar (Fig. 3B, middle and right). Interestingly, the opp mutant exhibited slightly increased resistance (about one dilution lower) to Ksg, which is contrary to the results on LB plates, whereas the dpp/opp mutant showed a higher level of resistance (four dilutions lower) to Ksg (Fig. 3B, middle). Furthermore, both mutants lacking the opp operon exhibited drastically increased resistance (at least five dilutions lower) to $\mathrm{BcS}$ as compared with WT and the $d p p$ mutant (Fig. $3 \mathrm{~B}$, right). These results suggest that the Dpp and Opp systems might function differently under different growth conditions and indicate that both Dpp and Opp participate in Ksg import, whereas the Opp system alone was sufficient for the uptake of $\mathrm{BcS}$ in MBMA medium.

\section{The Rcs system negatively regulates the expression of the opp operon.}

Our previous study using bioinformatics and microarray analysis revealed that the promoter region of the oppA2 gene contains a putative RcsAB box (TAAGA-N4-TCTGA) (Wang et al. 2012). It was also reported that RcsAB proteins specifically bind to promoters with a RcsAB box (Ancona et al. 2015; Lee et al. 2018). To determine the binding of RcsA/RcsB proteins to the oppA2 promoter region, an electrophoresis mobility shift assay (EMSA) was carried out using the oligonucleotide containing the $o p p A 2$ upstream sequence as a probe and a shifted band was observed with $R \operatorname{csB}$ and $R \operatorname{cs} A / R \operatorname{csB}$ proteins but not with the RcsA protein alone (Fig. 4A). Reverse transcription-quantitative polymerase chain reaction (qRTPCR) analysis showed that expression of the oppA gene was significantly higher (1.4-fold) in the $\operatorname{rcs} B$ mutant than that in the WT, while expression of the $d p p A$ gene was not significantly affected (Fig. 4B). Consistently, spot dilution assays showed that the $\operatorname{rcs} B$ mutant was slightly more sensitive to both Ksg (one dilution higher) and $\mathrm{BcS}$ (at least two dilutions higher) than was the WT strain on MBMA plates amended with $\mathrm{Ksg}$ at $50 \mu \mathrm{g} / \mathrm{ml}$ or BcS at $15 \mu \mathrm{g} / \mathrm{ml}$, respectively (Fig. 5). These results indicate that expression of the opp genes is negatively regulated by the Rcs system at the transcriptional level.

Table 3. Minimum inhibition concentration (MIC) in Luria Bertani medium for the wild-type (WT) and mutant strains

\begin{tabular}{lcc}
\hline & \multicolumn{2}{c}{ MIC $(\boldsymbol{\mu g} / \mathbf{m l})$} \\
\cline { 2 - 3 } Strains & Kasugamycin & Blasticidin S \\
\hline Ea1189 & 200 & 60 \\
$\Delta d p p A$ & 300 & 60 \\
$\Delta d p p A 2$ & 200 & 60 \\
$\Delta d p p A-F$ & 300 & 60 \\
$\Delta$ oppA & 200 & 65 \\
$\Delta$ oppA2 & 200 & 65 \\
$\Delta$ oppA2-F & 200 & 65 \\
$\Delta d p p A /$ oppA & 400 & 65 \\
$\Delta d p p A 2 /$ oppA2 & 200 & 65 \\
$\Delta d p p A-F /$ oppA2-F & 400 & 65 \\
$\Delta$ ksgA & 400 & N/D \\
\hline
\end{tabular}

${ }^{a} \mathrm{~N} / \mathrm{D}=$ not determined.

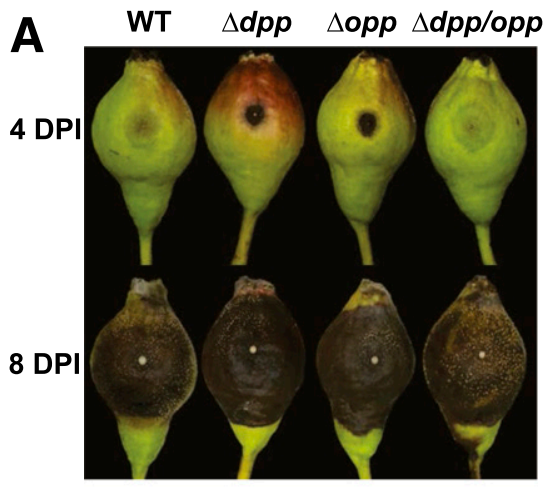

B

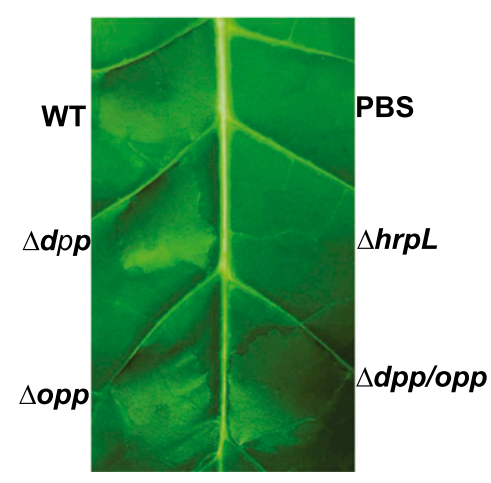

C

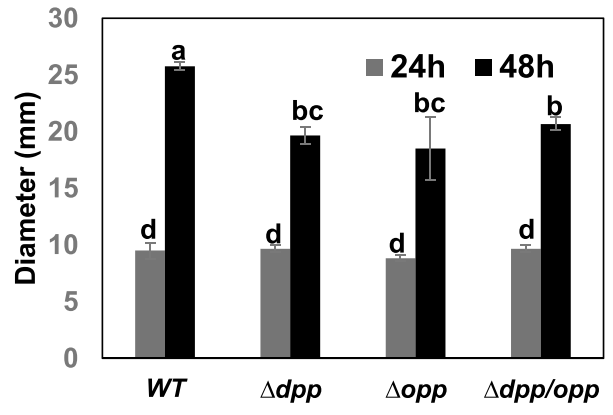

D

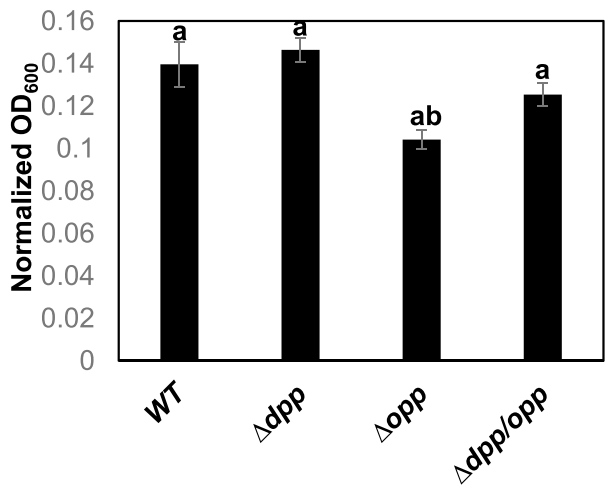

Fig. 2. Phenotypic assays. A and B, Virulence and hypersensitive response (HR) assays of Erwinia amylovora wild-type (WT) and mutant strains. A, Symptoms caused by the WT, $d p p, o p p$, and $d p p / o p p$ mutants on immature pear fruits. Immature pears were surface-sterilized, were pricked with a sterile needle, and were inoculated with $2 \mu \mathrm{l}$ of bacterial suspension. Photographs were taken at 4 and 8 days postinoculation. B, HR assay on tobacco leaves. The WT, $d p p, o p p$, and dpp/opp mutants were infiltrated into 8-week-old tobacco leaves. Phosphate-buffered saline (PBS) and the hrpL mutant strain were used as negative controls. Photographs were taken $24 \mathrm{~h}$ postinfiltration. $\mathbf{C}$ and $\mathbf{D}$, Effect of the $d p p$, opp, and dpp/opp mutations on motility and amylovoran production in Erwinia amylovora. C, Motility of the wild type (WT) and the $d p p$, opp, and $d p p / o p p$ mutant strains on tryptone agar plates $(0.3 \%)$ at $28^{\circ} \mathrm{C}$. Diameters of the movement circles were measured $48 \mathrm{~h}$ after inoculation. $\mathbf{D}$, Amylovoran production was determined at $24 \mathrm{~h}$ postinoculation in modified basal minimal medium. $d p p=$ the $d p p A-F$ mutant, $o p p=$ the $o p p A 2-F$ mutant, $d p p / o p p=$ the $d p p A-F / o p p A 2-F$ mutant. The values of distance or normalized optical density at $600 \mathrm{~nm}\left(\mathrm{OD}_{600}\right)$ are the means of three replicates. Error bars indicate standard deviation. The values marked with the same letter do not differ significantly $(P<0.05)$. 


\section{DISCUSSION}

Widespread use of antibiotics to combat diseases in human medicine and agriculture bears the risk of developing multidrug resistance. Since the 1970 s, streptomycin has been the primary tool in controlling fire blight disease, especially blossom blight. However, the extensive use of a single antibiotic leads to the emergence of streptomycin-resistant strains in the United States and elsewhere, which promotes the use of Ksg as an alternative or a replacement for fire blight control (McManus et al. 2002). Recent efficacy studies showed that Ksg exerts similar bactericidal effects as streptomycin against fire blight disease and Ksg was approved to be used as a viable alternative for orchards harboring streptomycin-resistant strains of E. amylovora (Adaskaveg et al. 2011; McGhee and Sundin 2011). In this study, we examined the sensitivity of E. amylovora strains to $\mathrm{Ksg}$ and $\mathrm{BcS}$ under two growth conditions and found that both antibiotics can gain access to cells through the two-peptide
ABC transporter systems, i.e., the Dpp and Opp systems. Lossof-function mutations in both complexes resulted in higher levels of resistance to both antibiotics, suggesting that development of resistance to $\mathrm{Ksg}$ and $\mathrm{BcS}$ in E. amylovora could possibly have occurred by mutations in these peptide transporters. In addition, we provided evidence that both the Dpp and Opp systems are not required for virulence, whereas expression of the opp operon is under the control of the Rcs phosphorelay system, which is essential for E. amylovora virulence (Wang et al. 2009; Zhao et al. 2009b).

In control of the fire blight disease, Ksg could be a longlasting alternative to streptomycin due to its lack of use in medicine and manageable phytotoxicity (Adaskaveg et al. 2011; McGhee and Sundin 2011). Both Ksg and streptomycin belong to the same class of aminoglycoside antibiotics that bind to the $30 \mathrm{~S}$ ribosomal subunit; however, streptomycin causes misreading of mRNA and aberrant proofreading at the A-site, whereas Ksg blocks binding of the initiator transfer RNA and
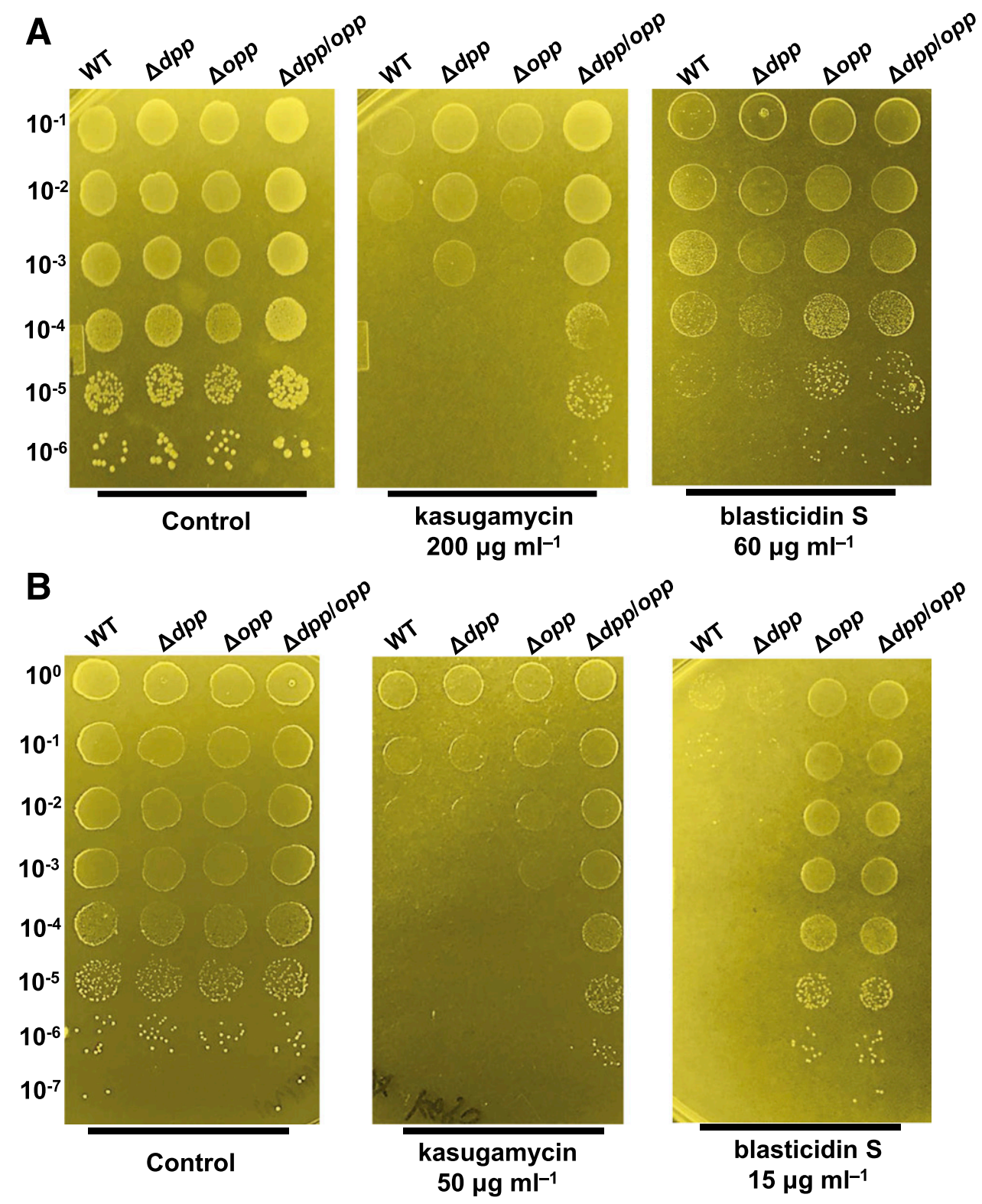

Fig. 3. Spot dilution assays for the dpp/opp mutant strains on A, Luria Bertani (LB) and B, modified basal minimal medium (MBMA) plates. Serial 10-fold dilutions were made from optical density at $600 \mathrm{~nm}\left(\mathrm{OD}_{600}\right)=0.1$ in $\mathrm{LB}$ and $\mathrm{OD}_{600}=1$ in MBMA, and $5 \mu$ for each dilution was added to plates containing no antibiotics (control), kasugamycin, or blasticidin $\mathrm{S}$ antibiotics as indicated. Photographs were taken $48 \mathrm{~h}$ postincubation. $d p p=$ the $d p p A-F$ mutant, $o p p=$ the oppA2-F mutant; $d p p / o p p=$ the $d p p A-F / o p p A 2-F$ mutant. 
messenger (m)RNA path at the P site (Schluenzen et al. 2006; Schuwirth et al. 2006; Wilson 2014). Resistance to streptomycin and Ksg can be developed by enzymatic inactivation, efflux pump, and mutation in the target sites (Benveniste and Davies 1973; Rosenberg et al. 2000; Schrag et al. 1997; Sparling 1970; Vila-Sanjurjo et al. 1999). In E. amylovora, reported streptomycin-resistant isolates contain either point mutations in the rpsL gene (encoding ribosomal protein S12) or the Tn5393 transposon carrying the $s t r A-s t r B$ resistance genes (McGhee et al. 2011; Russo et al. 2008). Although naturaloccurring Ksg-resistant isolates have not been reported in E. amylovora, artificial selection of spontaneous Ksg-resistant
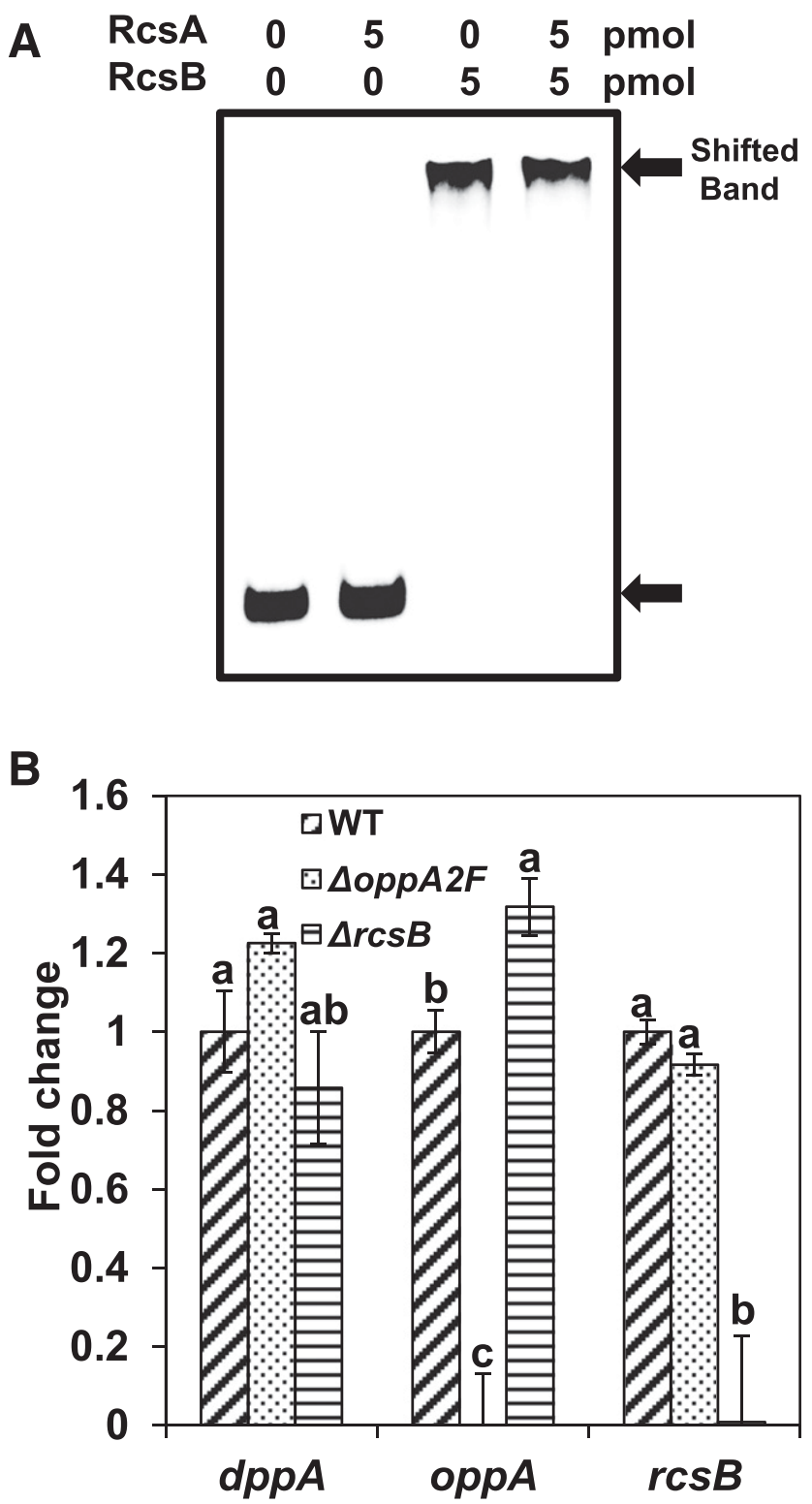

Fig. 4. The Rcs system negatively regulates the expression of the opp operon. A, Electrophoresis mobility shift assay for a 58-bp fragment of the upstream promoter sequence of the oppA2 and RcsA/RcsB proteins. Black arrows at the bottom and top indicate the free probe and the protein-DNA complex, respectively. The protein concentration (pmol) is indicated above each lane. B, Relative gene expression of the $\operatorname{dpp} A$, opp $A$, and $\operatorname{rcs} B$ in the opp and $r \operatorname{cs} B$ mutant strains as compared with the wild type (WT) in modified basal minimal medium at $18 \mathrm{~h}$ at $28^{\circ} \mathrm{C}$. The values of the relative fold change are the means of three replicates. The values marked with the same letter for each gene do not differ significantly $(P<0.05)$. Error bars indicate standard deviation. mutants in E. amylovora identified mutations in the $k s g A$ gene (McGhee and Sundin 2011). The ksgA gene encodes an adenine demethylase, which modifies the A794, G926, and A1519 nucleotides of the $16 \mathrm{~S}$ ribosomal RNA, and resistance to $\mathrm{Ksg}$ arises from lack of modification of these bases by KsgA or mutations in the ksgA gene (Sparling 1970; Vila-Sanjurjo et al. 1999). Our current study showed that the MIC for Ksg in the ksgA deletion mutant increased twofold, implying that mutation of the $k s g A$ gene could be one potential Ksg resistance mechanism or development of Ksg resistance in E. amylovora in the field. Our results also indicated that it is probably unlikely that development of Ksg resistance in the field is due to simultaneous mutations in Opp and Dpp systems, as both Opp and Dpp are required for full sensitivity to Ksg.

Previous studies have demonstrated that the peptide ABC importers in bacteria are responsible for illicit transport of multiple antibiotics, and mutations of these importers lead to higher levels of resistance (Ames et al. 1973; McKinney et al. 2015; Mistry et al. 2013; Pletzer et al. 2015; Shiver et al. 2016). The uptake of Ksg and BcS through the Dpp and Opp systems and its effect on antibiotic sensitivity were first reported in Escherichia coli (Acosta et al. 2000; Kashiwagi et al. 1992; Shiver et al. 2016). In P. aeruginosa, the Opp system is required for uptake of pacidamycin (Mistry et al. 2013), whereas another peptide $\mathrm{ABC}$ transporter, Npp, is required for uptake of peptidyl nucleotide antibiotics (Pletzer et al. 2015). Both Opp and Npp in $P$. aeruginosa also contribute to BcS sensitivity (Shiver et al. 2016). In this study, an increased resistance to Ksg and $\mathrm{BcS}$ in the $d p p$ and $o p p$ mutants was validated, suggesting another potential Ksg-resistance mechanism in E. amylovora. Our findings are novel in that antibiotic uptake by the ABC importers varies under different growth conditions, and the Dpp and Opp systems contribute more to Ksg sensitivity in rich and minimal media, respectively. Our results were in contrast to those reported in Escherichia coli in minimal medium, in which the Dpp system contributes more to the sensitivity of Ksg, whereas, in E. amylovora, the Opp system contributes more to both $\mathrm{Ksg}$ and $\mathrm{BcS}$ sensitivity. Furthermore, we found that both

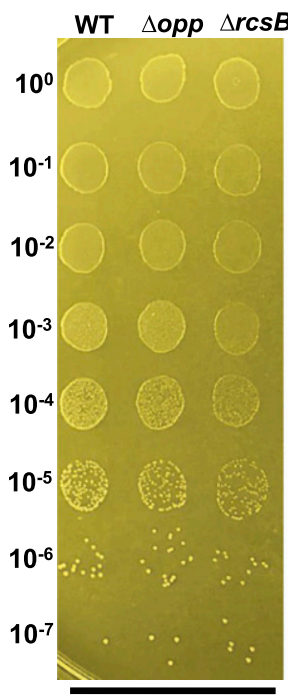

Control
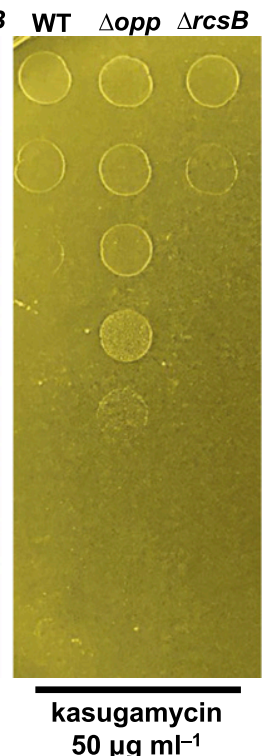

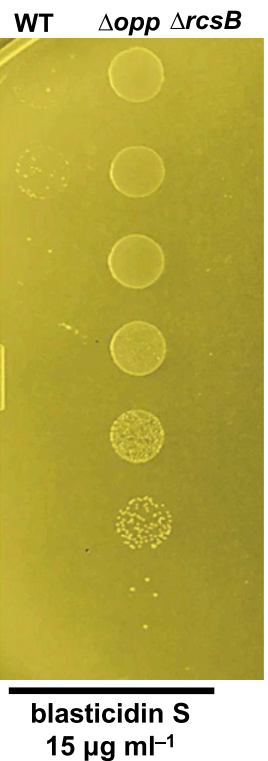

$15 \mu \mathrm{g} \mathrm{ml}^{-1}$
Fig. 5. Spot dilution assays for the $\operatorname{rcs} B$ mutant strain on modified basal minimal medium (MBMA) plates. Serial 10-fold dilutions were made from optical density at $600 \mathrm{~nm}=1$ in MBMA, and $5 \mu$ for each dilution was added to plates containing no antibiotics (control), kasugamycin, or blasticidin S. Antibiotics concentration as indicated. Photographs were taken $48 \mathrm{~h}$ postincubation. $o p p=$ the oppA2-F mutant. 
the Opp and Dpp systems in E. amylovora synergistically contribute to the sensitivity to Ksg in both rich and minimal media and deletion of opp alone was sufficient to confer a high level of resistance to $\mathrm{BcS}$ in minimal medium, which also differs from those reported in Escherichia coli (Shiver et al. 2016). We also proved that both the Opp and Dpp systems are not involved in the uptake of streptomycin and oxytetracycline (data not shown). Based on our results, we conclude that the Dpp and Opp systems in E. amylovora are responsible for illicit transport of and sensitivity to Ksg and BcS (Fig. 6).

In bacteria, $\mathrm{ABC}$ importers are responsible for the uptake of nutrients and might play a role in virulence (Abouhamad et al. 1991; Nikaido and Hall 1998; Weinberg and Maier 2007). Normally, substrate-binding proteins are used to capture amino acids, sugars, vitamins, metals, peptides, and various other ligands before their transport via the core of the ABC transporter (Davidson et al. 2008; Hollenstein et al. 2007; Zolnerciks et al. 2011). Originally, the major function of the Dpp and Opp permeases was found to be responsible for importing di-, tri-, and short chain peptides (less than five amino acids) as well as cell-wall peptides from the extracellular environment (Manson et al. 1986; Payne and Gilvarg 1968). In addition, under stress and starvation conditions, the Dpp and Opp systems could mediate the uptake of limiting nutrients such as proline betaine, nickel, and cobalt and intercellular signaling molecules (Alloing et al. 2006; Hiron et al. 2010; Remy et al. 2013). In Listeria monocytogenes, OppA is required for bacterial growth at low temperature and favors intracellular survival in macrophages (Borezee et al. 2000). In this study, we found that both the Opp and Dpp systems are dispensable for virulence on immature pear, suggesting that Dpp- or Opp-dependent nutrient acquisition might not be critical for one or both growth and virulence of E. amylovora.

In E. amylovora, the enterobacterial-specific Rcs phosphorelay system is essential for virulence by controlling the EPS amylovoran production and full type three secretion system gene expression through HrpS (Ancona et al. 2015; Lee and Zhao 2018; Lee et al. 2018; Wang et al. 2009, 2012; Zhao et al. $2009 b$ ). This system also interplays with the Gac-Csr posttranscriptional regulatory system by suppressing the expression csrB small (s)RNA (Ancona et al. 2016; Lee et al. 2018). In this study, we found that the Opp system is negatively regulated by the Rcs system at the transcription level. We further demonstrated that the $r \operatorname{cs} B$ mutant was slightly more sensitive to $\mathrm{Ksg}$ and $\mathrm{BcS}$ in minimal medium. These findings are novel and suggest that enterobacteria might indirectly employ the Rcs system to control the uptake of antibiotics and nutrients (Fig. 6). However, since RcsB is a global regulator of many genes in E. amylovora, including sRNA $c s r B$ and $h r p S$, we cannot rule out the possibility that other genes regulated by RcsB may also be involved in conferring sensitivity to Ksg and $\mathrm{BcS}$.

In summary, this study delivered two potential Ksg resistance mechanisms in E. amylovora, either through mutations of the Dpp/Opp systems or the $k s g A$ gene. So far, naturally occurring Ksg-resistant isolates have not been reported in E. amylovora; however, it is reasonable to assume that spontaneous $k s g A$ mutation in E. amylovora is more likely to occur in the field than is mutations in both the Dpp and Opp systems. As concerns over the development of antibiotic resistance in pathogens will continue to receive worldwide attention in the future, a comprehensive understanding of antibiotic-resistance mechanisms is therefore of pivotal importance that will help determine the risk in applying antibiotics in the field, detect resistance development in a pathogen, and develop improved control of diseases by reducing the application doses or times. We anticipate that our research will contribute to developing improved strategies of resistance management not only in E. amylovora but in other pathogens as well.

\section{MATERIALS AND METHODS}

\section{Bacterial strains and growth conditions.}

The bacterial strains and plasmids used in this study are listed in Table 2. LB broth was utilized for routine growth of E. amylovora and Escherichia coli strains and for determining the MIC of $\mathrm{Ksg}$ and $\mathrm{BcS}$. Both LB and a MBMA (3 $\mathrm{g}$ of $\mathrm{KH}_{2} \mathrm{PO}_{4}, 7 \mathrm{~g}$ of $\mathrm{K}_{2} \mathrm{HPO}_{4}, 1 \mathrm{~g}$ of $\left[\mathrm{NH}_{4}\right]_{2} \mathrm{SO}_{4}, 2 \mathrm{ml}$ of glycerol, $0.5 \mathrm{~g}$ of citric acid, $0.03 \mathrm{~g}$ of $\mathrm{MgSO}_{4}$ ) supplemented with $1 \%$ sorbitol (Wang et al. 2009) were used to determine Ksg and $\mathrm{BcS}$ sensitivity. Antibiotics were used at the following concentrations when appropriate: kanamycin $(\mathrm{Km}), 50 \mu \mathrm{g} / \mathrm{ml}$; ampicillin, $100 \mu \mathrm{g} / \mathrm{ml}$; and chloramphenicol $(\mathrm{Cm}), 10 \mu \mathrm{g} / \mathrm{ml}$. Primers used in this study for mutant construction, mutant confirmation, qRT-PCR, and EMSA are listed in Supplementary Table S1.

\section{Generation of mutants by $\boldsymbol{\lambda}$-red recombinase cloning.}

$E$. amylovora mutant strains were generated by the $\lambda$ phage recombinase method described previously (Datsenko and Wanner 2000; Zhao et al. 2009a). Briefly, overnight cultures of E. amylovora strains with pKD46 were inoculated in LB containing $0.1 \%$ arabinose and were grown to exponential phase (optical density at $600 \mathrm{~nm}\left[\mathrm{OD}_{600}\right]=0.8$ ). Cells were collected, made competent, and stored at $-80^{\circ} \mathrm{C}$. Recombination fragments consisting of either a $\mathrm{Cm}$ or $\mathrm{Km}$ gene with its own promoter, flanked by a 50-nucleotide homology arm, were generated by PCR using plasmid pKD32 or pKD13 as a template, respectively. PCR products were gel-purified and were introduced into the cells by electroporation. Transformants were selected on LB with appropriate antibiotics and were

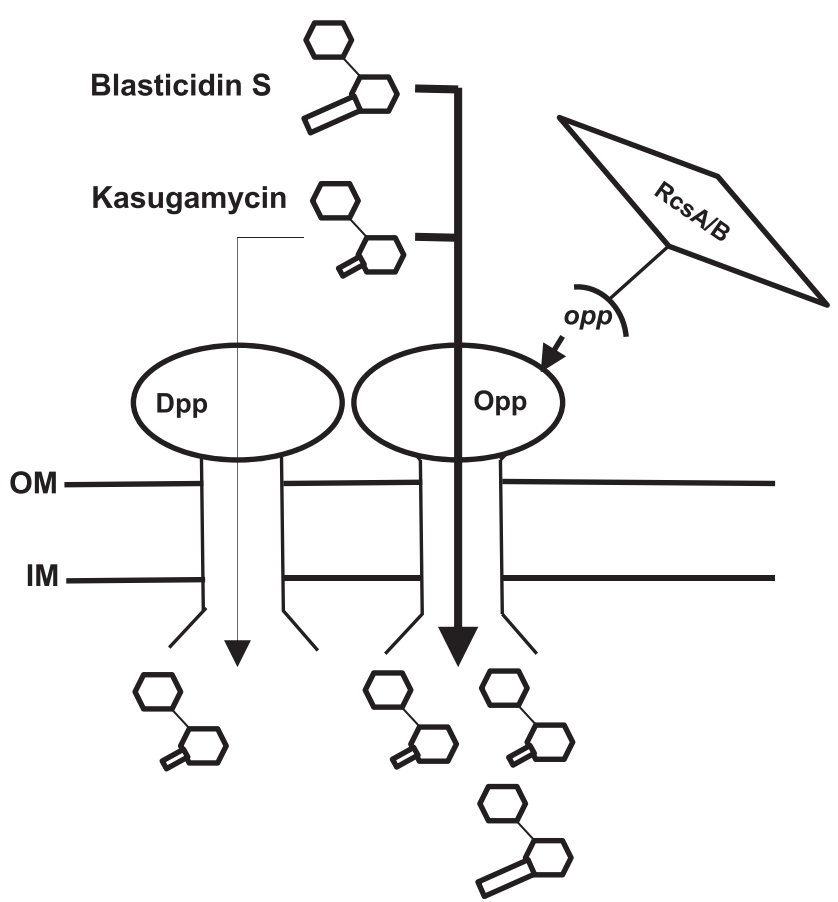

Fig. 6. Schematic model of the Dpp and Opp systems in uptake of antibiotics in Erwinia amylovora. This model is based on findings in a previous study in Escherichia coli (Shiver et al. 2016) as well as in this study. Uptake and positive regulation is indicated by arrows, and negative regulation is indicated by lines with blunt ends; Dpp = dipeptide permease, Opp = oligopeptide permease, $\mathrm{Rcs} \mathrm{A} / \mathrm{B}=$ two-component signal transduction system, $\mathrm{OM}=$ outer membrane, and $\mathrm{IM}=$ inner membrane. 
confirmed by PCR amplifications from the internal region of selection marker to the external region of the target gene. Double deletion mutants were generated using a single deletion mutant as the background strain.

\section{MIC determination.}

Briefly, overnight bacterial cultures were harvested by centrifugation and were adjusted to $\mathrm{OD}_{600}=0.0005$ in $\mathrm{LB}$ amended with antibiotics at different final concentrations (Ksg: 50, 100, 200,300 , and $400 \mu \mathrm{g} / \mathrm{ml}$; BcS: $15,55,60,65$, and $70 \mu \mathrm{g} / \mathrm{ml}$ ). After $24 \mathrm{~h}$ of incubation at $28^{\circ} \mathrm{C}$ with shaking, bacterial growth was determined by measuring $\mathrm{OD}_{600}$ and MIC was defined as concentration of antibiotics in which bacterial growth was $10 \%$ or less, as compared with that of the nonamended LB control. The experiments were performed in triplicate and were repeated at least three times.

\section{Spot dilution plate assay.}

Overnight bacterial cultures were harvested by centrifugation and cells were washed twice, using phosphate-buffered saline (PBS). Bacterial cells were resuspended in PBS and were adjusted to an initial concentration of $\mathrm{OD}_{600}=0.1$ and 1 for assays on LB and MBMA plates, respectively. Ten-fold series dilution of the bacterial suspension was made using PBS. For each dilution, $5 \mu$ l was spotted on the plates with or without antibiotics and was incubated at $28^{\circ} \mathrm{C}$ for $48 \mathrm{~h}$. Bacterial growth was visually observed on plates with or without antibiotics. Growth on plates without antibiotics was used as control to show similar growth of the WT and the mutants, whereas growth of mutants was compared with that of the WT on plates with antibiotics. If growth of the mutant was observed at least one dilution lower or higher than that of the WT, this indicated the mutant was more resistance or sensitive to antibiotics and vice versa. The experiments were performed in triplicate and were repeated at least three times.

\section{RNA isolation.}

After $18 \mathrm{~h}$ of incubation in MBMA at $28^{\circ} \mathrm{C}, 4 \mathrm{ml}$ of RNA protect reagent (Qiagen, Hilden, Germany) was added to $2 \mathrm{ml}$ of bacterial culture mixed by vortex and was incubated at room temperature for $5 \mathrm{~min}$. Cells were harvested by centrifugation, and RNA was extracted using RNeasy mini kit (Qiagen) according to the manufacturer's instructions. DNase I treatment was performed with TURBO DNA-free kit (Ambion, Austin, TX, U.S.A.), and the quality and quantity of the RNA were determined using a Nano-drop ND100 spectrophotometer (Nano-Drop Technologies, Wilmington, DE, U.S.A.).

\section{qRT-PCR.}

Total RNA $(1 \mu \mathrm{g})$ was reverse transcribed using Superscript III reverse transcription (Invitrogen, Carlsbad, CA, U.S.A.), following the manufacturer's instructions. Power SYBR Green PCR master mix (Applied Biosystems, Foster City, CA, U.S.A.) was mixed with cDNAs and selected primers to detect expression of target genes. qRT-PCR amplifications were performed using the StepOnePlus real-time PCR system (Applied Biosystems) under the following conditions: $50^{\circ} \mathrm{C}$ for $2 \mathrm{~min}$, $95^{\circ} \mathrm{C}$ for $10 \mathrm{~min}$, followed by 40 cycles of $95^{\circ} \mathrm{C}$ for $15 \mathrm{~s}$, and $60^{\circ} \mathrm{C}$ for $1 \mathrm{~min}$. The dissociation curve was measured after the program was completed and gene expression was analyzed with the relative quantification cycle threshold $(\Delta \Delta \mathrm{Ct})$ method, using the $r p o D$ gene as an endogenous control. The experiment was repeated at least twice and three technical replicates were included for each biological sample. Statistical analysis was performed using Student's $t$ test with $P<0.05$ considered as statistically significant.

\section{Virulence assays on immature pear fruits and HR assay on tobacco.}

Virulence assays were performed as described previously (Zhao et al. 2005, 2006). Briefly, overnight cultures of the WT and mutant strains were harvested by centrifugation and were suspended in PBS. Immature pear fruits (Pyrus communis L. cv. Bartlett) were surface-sterilized with $10 \%$ bleach, were pricked with a sterile needle, and were inoculated with $2 \mu \mathrm{l}$ of bacterial suspensions at $\mathrm{OD}_{600}=0.001$. Inoculated pears were incubated at $28^{\circ} \mathrm{C}$ in a humidity chamber, and disease symptoms were recorded at 4 and $8 \mathrm{dpi}$. The experiment was performed in triplicate and repeated at least three times.

For the HR assay, overnight cultures of the WT and mutant strains were harvested by centrifugation, were resuspended in PBS, and were adjusted to $\mathrm{OD}_{600}=0.1$. Bacterial suspension was infiltrated into tobacco leaves (Nicotiana tabacum) by needleless syringe. Infiltrated plants were kept in a humid growth chamber and HR symptoms were recorded at $24 \mathrm{~h}$ postinfiltration. The experiment was repeated three times.

\section{Amylovoran assay.}

Amylovoran concentration in the WT and mutant strains was quantitatively determined by the cetylpyrimidinium chloride (CPC) method, as previously described (Zhao et al. 2009b). Briefly, overnight cultures of bacterial strains were harvested by centrifugation and were washed three times with PBS. MBMA (5 ml) supplemented with $1 \%$ sorbitol was inoculated to a final $\mathrm{OD}_{600}$ of 0.2 and was incubated at $28^{\circ} \mathrm{C}$ with shaking. After $24 \mathrm{~h}, 1 \mathrm{ml}$ of each culture was centrifuged in an Eppendorf centrifuge at 7,000 rpm for $10 \mathrm{~min}$ and $50 \mu \mathrm{l}$ of CPC at $50 \mathrm{mg} / \mathrm{ml}$ was added to the supernatant. After $10 \mathrm{~min}$ of incubation, the turbidity of the suspension and cell density was determined by measuring $\mathrm{OD}_{600}$. Amylovoran was determined by normalizing the $\mathrm{OD}_{600}$ of the suspension to a cell density of 1.0. Each experiment was performed in triplicate and was repeated at least three times. Statistical analysis was performed using Student's $t$ test with $P<0.05$ considered as statistically significant.

\section{Motility assay.}

Bacterial cells were harvested by centrifugation and were washed three times with PBS after being grown overnight in LB with appropriate antibiotics. Bacterial suspensions were resuspended in PBS and were adjusted to an $\mathrm{OD}_{600}$ equal to 1.0, and $5 \mu \mathrm{l}$ was placed onto the center of motility plates $(10 \mathrm{~g}$ of tryptone, $5 \mathrm{~g}$ of $\mathrm{NaCl}, 3 \mathrm{~g}$ of agar per liter), as previously described (Zhao et al. 2009b). Plates were incubated at $28^{\circ} \mathrm{C}$ and movement diameters were measured at 24 and $48 \mathrm{~h}$ postinoculation. The experiments were performed in triplicate and were repeated at least three times. Statistical analysis was performed using Student's $t$ test, with $P<0.05$ considered as statistically significant.

\section{EMSA.}

EMSA for the analysis of the interaction between the $\mathrm{R} \operatorname{cs} \mathrm{A} / \mathrm{RcsB}$ proteins and the upstream regions of the oppA2 gene were performed as described previously (Ancona et al. 2015; Lee and Zhao 2016). Briefly, complementary oligonucleotides were $3^{\prime}$ biotinylated, using the biotin $3^{\prime}$ end DNA labeling kit (Pierce, Rockford, IL, U.S.A.) and were annealed before use. Reaction volumes of $10 \mu \mathrm{l}$ with $20 \mathrm{fmol}$ of labeled oligonucleotides were incubated with 5 pmol of either or both the RcsA and RcsB proteins in $1 \times$ binding buffer (Poly(dI.dC) at $50 \mathrm{ng} / \mu \mathrm{l}, 0.5 \mathrm{mM} \mathrm{MgCl} 2,0.1 \%$ Nonidet P-40, bovine serum albumin at $0.05 \mathrm{mg} / \mathrm{ml}$, and $5 \%$ glycerol). Reactions were incubated for $20 \mathrm{~min}$ at room temperature, were mixed with $2.5 \mu \mathrm{l}$ of $5 \times$ loading buffer, and were resolved into a $6 \%$ native polyacrylamide gel in $0.5 \times$ Tris-borate-EDTA buffer. The 
resolved reactions were transferred to a positively charged nylon membrane and were UV cross-linked. The chemiluminescent signals were developed using the lightshift chemiluminescent EMSA kit (Pierce) and were visualized using the ImageQuant LAS 4010 CCD camera (GE Healthcare, Piscataway, NJ, U.S.A.). The experiment was repeated twice.

\section{LITERATURE CITED}

Abouhamad, W. N., Manson, M., Gibson, M. M., and Higgins, C. F. 1991 Peptide transport and chemotaxis in Escherichia coli and Salmonella typhimurium: Characterization of the dipeptide permease (Dpp) and the dipeptide-binding protein. Mol. Microbiol. 5:1035-1047.

Acosta, M. B. R., Ferreira, R. C. C., Padilla, G., Ferreira, L. C. S., and Costa, S. O. P. 2000. Altered expression of oligopeptide-binding protein (OppA) and aminoglycoside resistance in laboratory and clinical Escherichia coli strains. J. Med. Microbiol. 49:409-413.

Adaskaveg, J. E., Driever, G. F., Förster, H., Gubler, W. D., Wade, M. L., and Holtz, B. 2008. Detection of Erwinia amylovora strains with reduced sensitivity to currently registered antibiotics and management of fire blight of pome fruits using kasugamycin in integrated strategies. Acta Hortic. 793:375-382.

Adaskaveg, J. E., Förster, H., Wade, M. L., and Holtz, B. 2011. Effectiveness of kasugamycin against Erwinia amylovora and its potential use for managing fire blight of pear. Plant Dis. 95:448-454.

Alloing, G., Travers, I., Sagot, B., Le Rudulier, D., and Dupont, L. 2006. Proline betaine uptake in Sinorhizobium meliloti: Characterization of Prb, an opp-like ABC transporter regulated by both proline betaine and salinity stress. J. Bacteriol. 188:6308-6317.

Ames, B. N., Ames, G. F., Young, J. D., Tsuchiya, D., and Lecocq, J. 1973. Illicit transport: The oligopeptide permease. Proc. Natl. Acad. Sci. U.S.A. 70:456-458.

Ancona, V., Chatnaparat, T., and Zhao, Y. 2015. Conserved aspartate and lysine residues of $\mathrm{RcsB}$ are required for amylovoran biosynthesis, virulence, and DNA binding in Erwinia amylovora. Mol. Genet. Genomics 290:1265-1276.

Ancona, V., Lee, J. H., and Zhao, Y. 2016. The RNA-binding protein CsrA plays a central role in positively regulating virulence factors in Erwinia amylovora. Sci. Rep. 6:37195.

Ancona, V., Li, W., and Zhao, Y. 2014. Alternative sigma factor RpoN and its modulation protein $\mathrm{YhbH}$ are indispensable for Erwinia amylovora virulence. Mol. Plant Pathol. 15:58-66.

Benveniste, R., and Davies, J. 1973. Aminoglycoside antibiotic-inactivating enzymes in actinomycetes similar to those present in clinical isolates of antibiotic-resistant bacteria. Proc. Natl. Acad. Sci. U.S.A. 70:2276-2280.

Borezee, E., Pellegrini, E., and Berche, P. 2000. OppA of Listeria monocytogenes, an oligopeptide-binding protein required for bacterial growth at low temperature and involved in intracellular survival. Infect. Immun. 68:7069-7077.

Copping, L. G., and Duke, S. O. 2007. Natural products that have been used commercially as crop protection agents. Pest Manag. Sci. 63:524-554.

Coyier, D. L., and Covey, R. P. 1975. Tolerance of Erwinia amylovora to streptomycin sulfate in Oregon and Washington. Plant Dis. Rep. 59: 849-852.

Datsenko, K. A., and Wanner, B. L. 2000. One-step inactivation of chromosomal genes in Escherichia coli K-12 using PCR products. Proc. Natl. Acad. Sci. U.S.A. 97:6640-6645

Davidson, A. L., Dassa, E., Orelle, C., and Chen, J. 2008. Structure, function, and evolution of bacterial ATP-binding cassette systems. Microbiol. Mol. Biol. Rev. 72:317-364.

Davis, G. S., and Mobley, H. L. 2005. Contribution of dppA to urease activity in Helicobacter pylori 26695. Helicobacter 10:416-423.

Goodell, E. W., and Higgins, C. F. 1987. Uptake of cell wall peptides by Salmonella typhimurium and Escherichia coli. J. Bacteriol. 169:3861-3865.

Hiles, I. D., Gallagher, M. P., Jamieson, D. J., and Higgins, C. F. 1987. Molecular characterization of the oligopeptide permease of Salmonella typhimurium. J. Mol. Biol. 195:125-142.

Hiles, I. D., and Higgins, C. F. 1986. Peptide uptake by Salmonella typhimurium. The periplasmic oligopeptide-binding protein. Eur. J. Biochem. 158:561-567.

Hiron, A., Posteraro, B., Carrière, M., Remy, L., Delporte, C., La Sorda, M., Sanguinetti, M., Juillard, V., and Borezée-Durant, E. 2010. A nickel ABC-transporter of Staphylococcus aureus is involved in urinary tract infection. Mol. Microbiol. 77:1246-1260.

Hollenstein, K., Dawson, R. J., and Locher, K. P. 2007. Structure and mechanism of $\mathrm{ABC}$ transporter proteins. Curr. Opin. Struct. Biol. 17: 412-418.
Jones, M. M., Johnson, A., Koszelak-Rosenblum, M., Kirkham, C., Brauer, A. L., Malkowski, M. G., and Murphy, T. F. 2014. Role of the oligopeptide permease ABC transporter of Moraxella catarrhalis in nutrient acquisition and persistence in the respiratory tract. Infect. Immun. 82:4758-4766

Kashiwagi, K., Miyaji, A., Ikeda, S., Tobe, T., Sasakawa, C., and Igarashi, K. 1992. Increase of sensitivity to aminoglycoside antibiotics by polyamineinduced protein (oligopeptide-binding protein) in Escherichia coli. J. Bacteriol. 174:4331-4337.

Koning, S. M., Elferink, M. G., Konings, W. N., and Driessen, A. J. 2001 Cellobiose uptake in the hyperthermophilic archaeon Pyrococcus furiosus is mediated by an inducible, high-affinity $\mathrm{ABC}$ transporter. J. Bacteriol. 183:4979-4984.

Lee, J. H., Ancona, V., and Zhao, Y. 2018. Lon protease modulates virulence traits in Erwinia amylovora by direct monitoring of major regulators and indirectly through the Rcs and Gac-Csr regulatory systems. Mol. Plant Pathol. 19:827-840.

Lee, J. H., and Zhao, Y. 2016. Integration host factor is required for RpoNdependent $h r p L$ gene expression and controls motility by positively regulating rsmB sRNA in Erwinia amylovora. Phytopathology 106:29-36.

Lee, J. H., and Zhao, Y. 2018. Integration of multiple stimuli-sensing systems to regulate HrpS and type III secretion system in Erwinia amylovora. Mol. Genet. Genomics 293:187-196.

Létoffé, S., Delepelaire, P., and Wandersman, C. 2006. The housekeeping dipeptide permease is the Escherichia coli heme transporter and functions with two optional peptide binding proteins. Proc. Natl. Acad. Sci. U.S.A. 103:12891-12896.

Mankin, A. 2006. Antibiotic blocks mRNA path on the ribosome. Nat. Struct. Mol. Biol. 13:858-860.

Manson, M. D., Blank, V., Brade, G., and Higgins, C. F. 1986. Peptide chemotaxis in E. coli involves the Tap signal transducer and the dipeptide permease. Nature 321:253-256.

McGhee, G. C., Guasco, J., Bellomo, L. M., Blumer-Schuette, S. E., Shane, W. W., Irish-Brown, A., and Sundin, G. W. 2011. Genetic analysis of streptomycin-resistant $\left(\mathrm{Sm}^{\mathrm{R}}\right)$ strains of Erwinia amylovora suggests that dissemination of two genotypes is responsible for the current distribution of $\mathrm{Sm}^{\mathrm{R}}$ E. amylovora in Michigan. Phytopathology 101:182-191.

McGhee, G. C., and Sundin, G. W. 2011. Evaluation of kasugamycin for fire blight management, effect on nontarget bacteria, and assessment of kasugamycin resistance potential in Erwinia amylovora. Phytopathology 101:192-204

McKinney, D. C., Bezdenejnih-Snyder, N., Farrington, K., Guo, J., McLaughlin, R. E., Ruvinsky, A. M., Singh, R., Basarab, G. S., Narayan, S., and Buurman, E. T. 2015. Illicit transport via dipeptide transporter Dpp is irrelevant to the efficacy of negamycin in mouse thigh models of Escherichia coli infection. ACS Infect. Dis. 1:222-230.

McManus, P. S., Stockwell, V. O., Sundin, G. W., and Jones, A. L. 2002. Antibiotic use in plant agriculture. Annu. Rev. Phytopathol. 40:443-465.

Mistry, A., Warren, M. S., Cusick, J. K., Karkhoff-Schweizer, R. R., Lomovskaya, O., and Schweizer, H. P. 2013. High-level pacidamycin resistance in Pseudomonas aeruginosa is mediated by an opp oligopeptide permease encoded by the opp-fabI operon. Antimicrob. Agents Chemother. 57:5565-5571.

Myung, I. S., Lee, J. Y., and Yun, M. J. 2016. Fire blight of apple, caused by Erwinia amylovora, a new disease in Korea. Plant Dis. 100:1774.

Nikaido, H., and Hall, J. A. 1998. Overview of bacterial ABC transporters. Methods Enzymol. 292:3-20.

Norelli, J. L., Holleran, H. T., Johnson, W. C., Robinson, T. L., and Aldwinckle, H. S. 2003. Resistance of Geneva and other apple rootstocks to Erwinia amylovora. Plant Dis. 87:26-32.

Payne, J. W., and Gilvarg, C. 1968. Size restriction on peptide utilization in Escherichia coli. J. Biol. Chem. 243:6291-6299.

Payne, J. W., Payne, G. M., Gupta, S., Marshall, N. J., and Grail, B. M. 2001. Conformational limitations of glycylsarcosine as a prototypic substrate for peptide transporters. Biochim. Biophys. Acta 1514:65-75.

Pletzer, D., Braun, Y., Dubiley, S., Lafon, C., Köhler, T., Page, M. G. P., Mourez, M., Severinov, K., and Weingart, H. 2015. The Pseudomonas aeruginosa $\mathrm{PA} 14 \mathrm{ABC}$ transporter $\mathrm{NppA} 1 \mathrm{~A} 2 \mathrm{BCD}$ is required for uptake of peptidyl nucleoside antibiotics. J. Bacteriol. 197:2217-2228.

Pletzer, D., Lafon, C., Braun, Y., Köhler, T., Page, M. G. P., Mourez, M., and Weingart, H. 2014. High-throughput screening of dipeptide utilization mediated by the $\mathrm{ABC}$ transporter DppBCDF and its substrate-binding proteins DppA1-A5 in Pseudomonas aeruginosa. PLoS One 9: e111311.

Podbielski, A., and Leonard, B. A. 1998. The group A streptococcal dipeptide permease (Dpp) is involved in the uptake of essential amino acids and affects the expression of cysteine protease. Mol. Microbiol. 28 : 1323-1334. 
Remy, L., Carrière, M., Derré-Bobillot, A., Martini, C., Sanguinetti, M., and Borezée-Durant, E. 2013. The Staphylococcus aureus Opp1 ABC transporter imports nickel and cobalt in zinc-depleted conditions and contributes to virulence. Mol. Microbiol. 87:730-743.

Rosenberg, E. Y., Ma, D., and Nikaido, H. 2000. AcrD of Escherichia coli is an aminoglycoside efflux pump. J. Bacteriol. 182:1754-1756.

Russo, N. L., Burr, T. J., Breth, D. I., and Aldwinckle, H. S. 2008. Isolation of streptomycin-resistant isolates of Erwinia amylovora in New York. Plant Dis. 92:714-718.

Schluenzen, F., Takemoto, C., Wilson, D. N., Kaminishi, T., Harms, J. M., Hanawa-Suetsugu, K., Szaflarski, W., Kawazoe, M., Shirouzu, M., Nierhaus, K. H., Yokoyama, S., and Fucini, P. 2006. The antibiotic kasugamycin mimics mRNA nucleotides to destabilize tRNA binding and inhibit canonical translation initiation. Nat. Struct. Mol. Biol. 13: 871-878.

Schrag, S. J., Perrot, V., and Levin, B. R. 1997. Adaptation to the fitness costs of antibiotic resistance in Escherichia coli. Proc. Biol. Sci. 264:1287-1291.

Schuwirth, B. S., Day, J. M., Hau, C. W., Janssen, G. R., Dahlberg, A. E., Cate, J. H., and Vila-Sanjurjo, A. 2006. Structural analysis of kasugamycin inhibition of translation. Nat. Struct. Mol. Biol. 13: 879-886.

Shiver, A. L., Osadnik, H., Kritikos, G., Li, B., Krogan, N., Typas, A., and Gross, C. A. 2016. A chemical-genomic screen of neglected antibiotics reveals illicit transport of kasugamycin and blasticidin S. PLoS Genet. 12:e1006124.

Smith, M. W., Tyreman, D. R., Payne, G. M., Marshall, N. J., and Payne, J. W. 1999. Substrate specificity of the periplasmic dipeptide-binding protein from Escherichia coli: Experimental basis for the design of peptide prodrugs. Microbiology 145:2891-2901.

Smits, T. H., Rezzonico, F., and Duffy, B. 2011. Evolutionary insights from Erwinia amylovora genomics. J. Biotechnol. 155:34-39.

Smits, T. H., Rezzonico, F., Kamber, T., Blom, J., Goesmann, A., Frey, J. E., and Duffy, B. 2010. Complete genome sequence of the fire blight pathogen Erwinia amylovora CFBP 1430 and comparison to other Erwinia spp. Mol. Plant-Microbe Interact 23:384-393.

Solomon, J., Su, L., Shyn, S., and Grossman, A. D. 2003. Isolation and characterization of mutants of the Bacillus subtilis oligopeptide permease with altered specificity of oligopeptide transport. J. Bacteriol. 185:6425-6433.

Sparling, P. F. 1970. Kasugamycin resistance: 30 S ribosomal mutation with an unusual location on the Escherichia coli chromosome. Science 167: 56-58.

Takeuchi, S., Hirayama, K., Ueda, K., Sakai, H., and Yonehara, H. 1958. Blasticidin S, a new antibiotic. J. Antibiot. 11:1-5.

Umezawa, H., Okami, Y., Hashimoto, T., Suhara, Y., Hamada, M., and Takeuchi, T. 1965. A new antibiotic, kasugamycin. J. Antibiot. Ser A 18:101-103. van der Zwet, T., Orolaza-Halbrendt, N., and Zeller, W. 2012. Fire Blight, History, Biology, and Management. APS Press, St.Paul, MN, U.S.A..

Vila-Sanjurjo, A., Squires, C. L., and Dahlberg, A. E. 1999. Isolation of kasugamycin resistant mutants in the $16 \mathrm{~S}$ ribosomal RNA of Escherichia coli. J. Mol. Biol. 293:1-8.

Wang, D., Korban, S. S., and Zhao, Y. 2009. The Rcs phosphorelay system is essential for pathogenicity in Erwinia amylovora. Mol. Plant Pathol. 10:277-290.

Wang, D., Qi, M., Calla, B., Korban, S. S., Clough, S. J., Cock, P. J., Sundin, G. W., Toth, I., and Zhao, Y. 2012. Genome-wide identification of genes regulated by the Rcs phosphorelay system in Erwinia amylovora. Mol. Plant-Microbe Interact 25:6-17.

Weinberg, M. V., and Maier, R. J. 2007. Peptide transport in Helicobacter pylori: Roles of dpp and opp systems and evidence for additional peptide transporters. J. Bacteriol. 189:3392-3402.

Wilson, D. N. 2014. Ribosome-targeting antibiotics and mechanisms of bacterial resistance. Nat. Rev. Microbiol. 12:35-48.

Yamaguchi, H., Yamamoto, C., and Tanaka, N. 1965. Inhibition of protein synthesis by blasticidin S. I. Studies with cell-free systems from bacterial and mammalian cells. J. Biochem. 57:667-677.

Yazgan, A., Ozcengiz, G., and Marahiel, M. A. 2001. Tn10 insertional mutations of Bacillus subtilis that block the biosynthesis of bacilysin. Biochim. Biophys. Acta 1518:87-94.

Yoon, H. J., Kim, H. J., Mikami, B., Yu, Y. G., and Lee, H. H. 2016. Crystal structure of a putative oligopeptide-binding periplasmic protein from a hyperthermophile. Extremophiles 20:723-731.

Zhao, Y., Blumer, S. E., and Sundin, G. W. 2005. Identification of Erwinia amylovora genes induced during infection of immature pear tissue. J. Bacteriol. 187:8088-8103.

Zhao, Y., He, S. Y., and Sundin, G. W. 2006. The Erwinia amylovora avrRpt $2_{E A}$ gene contributes to virulence on pear and AvrRpt $2_{\mathrm{EA}}$ is recognized by Arabidopsis RPS2 when expressed in pseudomonas syringae. Mol. Plant-Microbe Interact 19:644-654.

Zhao, Y., Sundin, G. W., and Wang, D. 2009a. Construction and analysis of pathogenicity island deletion mutants of Erwinia amylovora. Can. J. Microbiol. 55:457-464.

Zhao, Y., Wang, D., Nakka, S., Sundin, G. W., and Korban, S. S. 2009b. Systems level analysis of two-component signal transduction systems in Erwinia amylovora: Role in virulence, regulation of amylovoran biosynthesis and swarming motility. BMC Genomics 10:245.

Zhao, Y. F. 2014. Genomics of Erwinia amylovora and related Erwinia species associated with pome fruit trees. Pages 1-36 in: Genomics of Plant-Associated Bacteria. D. Gross, A. Lichens-Park, and C. Kole, eds. Springer, Berlin.

Zolnerciks, J. K., Andress, E. J., Nicolaou, M., and Linton, K. J. 2011. Structure of ABC transporters. Essays Biochem. 50:43-61. 